\title{
Association of HLA-Bw46DR9 combination with juvenile myasthenia gravis in Chinese
}

\author{
Wei-Hung Chen, Hou-Chang Chiu, Rong-Phong Hseih
}

\begin{abstract}
One hundred and fifty two Chinese patients with myasthenia gravis in Taiwan were investigated for HLA-A, B, $C$ and DR/DQ typing. HLA-Bw46 and DR9 frequencies were significantly increased in patients compared with the control group, and there was a decrease in DR3. Further analysis between different subgroups of patients showed Bw46 and DR9 were more significantly increased in the juvenile group than in the adult group. No single HLA allele was associated with either clinical type or thymic pathology, but there was an excess of BW46DR9 combination in both juvenile and ocular type patients. The Chinese population with myasthenia gravis is characterised by earlier age at onset, more ocular forms and less clinically severe illness than in whites, and these characteristics indicate a special subgroup that correlates with the strong Bw46DR9 association.
\end{abstract}

(F Neurol Neurosurg Psychiatry 1993;56:382-385)

Myasthenia gravis is a well recognised autoimmune disease which affects neuromuscular junctions. The aberrant immune response is believed in part to be caused by genetic factors. Two lines of research have associated disease susceptibility to human genes, that is, immunoglobulin allotypes ${ }^{1}$ and human leukocyte antigens (HLA). The associations between myasthenia gravis and HLA antigens have been discussed frequently and show interesting ethnic differences: HLA-B8 and DR3 in whites, ${ }^{2}$ A1, B8 and DR5 in American blacks, ${ }^{3}$ DR9 and DRw8 in Japanese $^{4}$ and Bw46 and DR9 in Chinese. ${ }^{5-9}$ Furthermore the disease is heterogeneous with different HLA associations in different subgroups of patients; for example, in whites A3, B7 and DR2 frequencies are increased in males and, in patients with onset over the age of 40, low titres of acetylcholine receptor antibody and prevalence of striated muscle antibody are characteristic; conversely there is a stronger A1, B8 and DR3 association in females and, in cases with onset below the age of 40, high titres of AChR antibody and thymic hyperplasia. ${ }^{2}$

The Chinese population with myasthenia gravis characteristically shows earlier onset, more ocular cases and fewer severe cases in contrast to the white population. ${ }^{10}$ The HLA antigen associations are also distinct. The difference is intriguing and raises questions as to whether the ethnic difference in disease manifestation is HLA associated and, furthermore, genetically determined. To clarify the HLA associations in Chinese patients and compare them with those in whites, we have analysed HLA antigens in 152 Chinese myasthenic patients, with emphasis on the HLA combinations and correlation with different clinical subgroup.

\section{Patients and methods}

\section{Patients}

One hundred and fifty two Chinese patients with myasthenia gravis seen at the Department of Neurology, National Taiwan University Hospital were collected for HLAA, B, C, DR and DQ typing. The diagnosis was based on clinical, electrophysiological and pharmacological findings. All patients were regularly followed up. The patients consisted of 58 males and 94 females; age ranged from 1 to 68 years. Clinically, 64 cases belonged to grade I, 63 belonged to IIa, 22 to IIb, 2 to III and 1 to IV. Among them, 54 patients received thymectomy: 13 had a thymoma, 25 a hyperplastic thymus and 16 an atrophic thymus. Single fibre electromyography was performed on 121 patients (Medelec MS21, UK). The results of single fibre jitter were expressed as mean consecutive difference. ${ }^{11}$ The control group consisted of 202 unrelated Chinese of similar ethnic origins for HLA-A, B, C typing and 107 for D/DR and DQ typing. None of them had a history of neuromuscular diseases.

\section{Methods}

Peripheral lymphocytes separated by FicollHypaque density gradient centrifugation were used for HLA-A, B, C typing; B-cells were further enriched using Lymphokwik B-cell isolation reagent (One Lambda Inc, California, United States) and were tested for HLA-D/DR and DQ typing. HLA typing was performed by standard microcytotoxicity assay using Terasaki's oriental trays (One Lambda Inc).

\section{Statistical analysis}

The HLA frequencies in patients and the normal control were compared using the $\chi^{2}$ test with Yates' correction. The probabilities were further corrected by multiplying the numbers of types tested (23 for HLA-A,B,C, 10 for HLA-DR, 3 for HLA-DQw, and 2 for 
Table 1 Selected HLA frequencies in Chinese patients with myasthenia gravis and controls.

\begin{tabular}{|c|c|c|c|c|c|}
\hline \multirow[b]{2}{*}{$H L A$} & \multicolumn{2}{|c|}{$M G(152)$} & \multicolumn{3}{|c|}{$\begin{array}{l}\text { Control } \\
(202 \text { for } A, B, C, 107 \text { for } D)\end{array}$} \\
\hline & No. & $\%$ & No. & $\%$ & $\chi^{2}$ \\
\hline A2 & 90 & $59 \cdot 2$ & 87 & $43 \cdot 1$ & $8 \cdot 4$ \\
\hline A9 & 41 & $27 \cdot 0$ & 76 & $37 \cdot 6$ & \\
\hline A10 & 4 & $2 \cdot 6$ & 9 & 4.5 & \\
\hline A11 & 82 & 53.9 & 106 & 52.5 & \\
\hline B7 & 4 & $2 \cdot 6$ & 5 & $2 \cdot 5$ & \\
\hline B8 & 2 & $1 \cdot 3$ & 2 & $1 \cdot 0$ & \\
\hline B12 & 1 & 0.1 & 1 & 0.5 & \\
\hline Bw46 & 64 & $42 \cdot 1$ & 35 & $17 \cdot 3$ & $25 \cdot 2^{\star}$ \\
\hline Cwl & 74 & $48 \cdot 7$ & 49 & 26.8 & $7 \cdot 3$ \\
\hline Cw3 & 47 & 30.9 & 73 & $36 \cdot 1$ & \\
\hline DR2 & 31 & 20.4 & 24 & 22.4 & \\
\hline DR3 & 8 & $5 \cdot 3$ & 35 & 32.7 & $32 \cdot 2^{\star}$ \\
\hline DR4 & 51 & 33.6 & 36 & 33.6 & \\
\hline DRw8 & 5 & $3 \cdot 3$ & 6 & $5 \cdot 6$ & \\
\hline DR9 & 82 & 53.9 & 16 & $15 \cdot 0$ & $39 \cdot 0^{\star}$ \\
\hline DQw1 & 53 & 34.9 & 43 & $40 \cdot 2$ & \\
\hline DQw3 & 97 & 63.8 & 68 & 63.6 & \\
\hline
\end{tabular}

DRw52 and DRw53). The HLA frequencies in different subgroups of patients were also analysed by the $\chi^{2}$ test with Yates' correction and Fisher's exact probability test. Student's $t$ test was used to compare age at onset and mean consecutive difference between patients with different HLA antigens.

Results

The frequencies of HLA antigens in 152 Chinese patients and the control group (202 for HLA-A, B, C typing and 107 for D/DR and DQ typing) are shown in table 1 . Bw46 and DR9 were both significantly increased in the patient group whereas DR3 was significantly decreased.

The patients with thymoma were excluded in the further analysis so as not to dilute the results from the other patients. Different subgroups in terms of sex, age at onset, ocular or generalised clinical type, thymic pathology and result of single fibre EMG (mean consecutive difference) were then analysed (table 2). On comparison with the control group, A2

Table 2 Selected HLA frequencies in various subgroups of non-thymoma patients with myasthenia gravis.

\begin{tabular}{|c|c|c|c|c|c|c|}
\hline & $M G$ & $A 2$ & $B W 46$ & $C w 1$ & $D R 9$ & $B W 46 D R 9$ \\
\hline Control frequencies & & $43 \cdot 1 \%$ & $17 \cdot 3 \%$ & $26 \cdot 8 \%$ & $15 \cdot 0 \%$ & $7 \cdot 0 \%$ \\
\hline $\begin{array}{l}\text { Total } \\
\text { Sex }\end{array}$ & 139 & $83(60 \%)$ & $60(43 \%)$ & $54(39 \%)$ & $78(56 \%)$ & $50(36 \%)$ \\
\hline M & $\begin{array}{l}51 \\
88\end{array}$ & $\begin{array}{l}35(69 \%)^{\star} \\
48(55 \%)\end{array}$ & $\begin{array}{l}24(47 \%)^{\star} \\
36(41 \%)^{\star}\end{array}$ & $\begin{array}{l}22(43 \%) \\
32(36 \%)\end{array}$ & $\begin{array}{l}28(55 \%)^{\star} \\
50(57 \%)^{\star}\end{array}$ & $\begin{array}{l}20(39 \%) \\
30(34 \%)\end{array}$ \\
\hline $\begin{array}{l}\text { Age at onset } \\
\leqslant 5 \\
\leqslant 10 \\
\leqslant 20 \\
>20\end{array}$ & $\begin{array}{r}9 \\
27 \\
67 \\
72\end{array}$ & $\begin{array}{r}5(55 \%) \\
20(74 \%) \\
39(58 \%) \\
44(61 \%)\end{array}$ & $\begin{array}{l}6(67 \%)^{\star} \\
17(63 \%)^{\star} \\
40(60 \%)^{\star a} \\
20(28 \%)\end{array}$ & $\begin{array}{l}4(44 \%)^{\star \star} \\
12(44 \%)^{\star \star} \\
32(48 \%)^{\star \star} \\
22(31 \%)\end{array}$ & $\begin{array}{c}6(67 \%)^{\star} \\
19(70 \%)^{\star} \\
45(67 \%)^{\star \downarrow} \\
33(46 \%)^{\star}\end{array}$ & $\begin{array}{l}4(54 \%)^{\star} \\
14(52 \%)^{\star} \\
35(52 \%)^{\star c} \\
15(21 \%)\end{array}$ \\
\hline $\begin{array}{l}\text { Clinical type } \\
\text { Ocular } \\
\text { Generalized } \\
\text { Thymic pathology }\end{array}$ & $\begin{array}{l}64 \\
75\end{array}$ & $\begin{array}{l}37(58 \%) \\
46(61 \%)\end{array}$ & $\begin{array}{l}32(50 \%)^{\star} \\
28(37 \%)^{\star \star}\end{array}$ & $\begin{array}{l}26(41 \%) \\
28(37 \%)\end{array}$ & $\begin{array}{l}40(63 \%)^{\star} \\
38(51 \%)^{\star}\end{array}$ & $\begin{array}{l}28(44 \%)^{\star \star d} \\
22(29 \%)\end{array}$ \\
\hline $\begin{array}{l}\text { Hyperplasia } \\
\text { Atrophy }\end{array}$ & $\begin{array}{r}25 \\
16 \\
112\end{array}$ & $\begin{array}{l}13(52 \%) \\
10(63 \%)\end{array}$ & $\begin{array}{r}10(44 \%) \\
8(50 \%)\end{array}$ & $\begin{array}{r}10(40 \%) \\
8(50 \%)\end{array}$ & $\begin{array}{l}14(56 \%)^{\star} \\
10(63 \%)^{\star}\end{array}$ & $\begin{array}{l}9(36 \%) \\
6(38 \%)\end{array}$ \\
\hline $\begin{array}{l}\text { MCD } \\
\leqslant 55 \\
55-100 \\
>100 \dagger \\
\text { Mean MCD }(\mu \mathrm{s})\end{array}$ & $\begin{array}{l}112 \\
59 \\
25 \\
28 \\
75 \cdot 2\end{array}$ & $\begin{array}{l}32(54 \%) \\
16(64 \%) \\
21(75 \%) \\
81 \cdot 3\end{array}$ & $\begin{array}{l}26(44 \%) \\
10(40 \%) \\
10(36 \%) \\
71 \cdot 6\end{array}$ & $\begin{array}{l}24(41 \%) \\
10(36 \%) \\
11(32 \%) \\
69 \cdot 7\end{array}$ & $\begin{array}{l}38(64 \%) \\
15(60 \%) \\
13(46 \%) \\
68 \cdot 6\end{array}$ & $\begin{array}{l}24(41 \%) \\
9(36 \%) \\
8(29 \%) \\
70 \cdot 1\end{array}$ \\
\hline
\end{tabular}

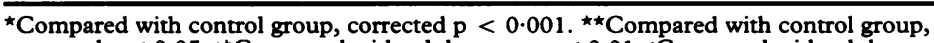
corrected $p<0.05$. "Compared with adult group, $p<0.01$. COmpared with adult group, $\mathrm{p}<0.001$. ${ }^{\mathrm{d}}$ Compared with generalized type, $\mathrm{p}<0.05$.

tImplies more severe weakness. was increased in male patients, regardless of age at onset and clinical type; Bw46 was increased in juvenile patients (age of onset 20 or under) and both clinical types, regardless of sex; Cwl was increased in juvenile patients; DR9 was increased in all subgroups of patients.

HLA frequencies were also compared in individual subgroups. Bw46 and DR9 were significantly increased in the juvenile group compared with the adult group. No single HLA antigen was confined to any one clinical type or thymic pathology. Bw46DR9 combination was significantly increased in patients with juvenile and ocular forms (table 2). Inclusion of other HLA antigens (for example, A2) showed no further correlation.

The association of Bw46 and DR9 with myasthenia gravis was strongest before age 20 and declined thereafter (fig 1), so that patients with either Bw46 or DR9 were significantly younger than those without. The mean age at onset in patients positive and negative for Bw46 was: 20.7 v 29.0, $t=-3.59, \mathrm{p}<0.001$; mean age at onset in patients positive and negative for DR9 was: $23.3 v 29.0, t=-2.24, \mathrm{p}=0.02$. The associations seemed to result from the Bw46DR9 combination (mean age at onset: 18.7 ) as neither Bw46 nor DR9 alone was associated with younger age of onset after removing the Bw46DR9 combination from the calculation (table 3).

No association between thymic pathology and HLA was noted. Even in the thymoma group which was represented by older age of onset, however, those with Bw46 were still younger than those without. Mean age at onset in patients with thymoma positive and negative for Bw46 was: $25 \cdot 7 v 44 \cdot 9, t=2 \cdot 87$, $\mathrm{p}<0.05$. The only juvenile patient with thymoma with onset at only 8 years, is Bw46DR9 positive.

Mean consecutive difference was chosen to represent clinical severity. ${ }^{12}$ It tended to be lower in patients with Bw46 or DR9 as well as the Bw46DR9 combination, but the differences were not statistically significant.

\section{Discussion}

This study is one of the largest series in the study of HLA antigens in Chinese patients with myasthenia gravis and clearly confirms the association with HLA Bw46 and DR9. Hawkins et al $^{5}$ first described strong association of Bw46 with juvenile onset myasthenia gravis in Hong Kong Chinese, but at that time they did not perform DR/DQ typing. In a later report $^{7}$ they pointed out that Bw46 was not increased in adult patients; however, when adult patients were separated on the basis of presence or absence of acetylcholine receptor antibodies, Bw46 showed increased prevalence in patients without such antibodies. Another study ${ }^{6}$ conducted on Taiwan Chinese showed increased A2 and DR9 frequencies, although in this study Bw46 was not tested, and they were unable to correlate the HLA prevalence with any subgroup of 


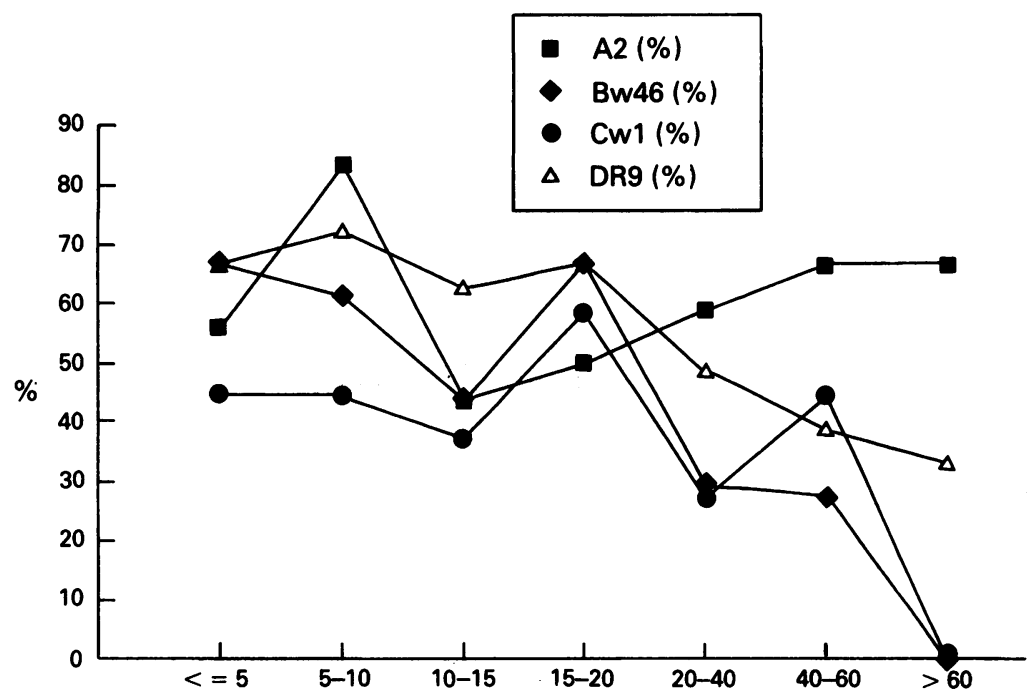

Figure HLA frequencies in relation to different age at onset. Bw46 and DR9 show the strongest association with age at onset before 20 years and declined thereafter. The frequencies in the juvenile patients are evenly distributed: those of the very young onset age, that is, below 5 or 10 years, are similar to those of the older onset age, that is, between 10 and 20 years. their myasthenia gravis patients. In our previous report, Bw46 and DR9 were both increased. Further analysis showed that the primary association was with DR9 and the increase in Bw46 was secondary to it. ${ }^{8}$ The result was accepted as linkage disequilibrium between Bw46 and DR9. ${ }^{13}$ The strong association with DR9 was again proposed by Hawkins et al ${ }^{14}$ who stressed the association with ocular myasthenia, onset in the first two decades of life and absence or low titres of acetylcholine receptor antibody. In the present study, a similar association with juvenile onset and ocular type myasthenia gravis is observed. Such association, however, seems to result from the Bw46DR9 combination, for neither Bw46 nor DR9 alone shows such close association. Although we did not perform complement allotyping, our observation is in agreement with the concept of a distinct supratype of Bw46, BfS, C4A4, C4B2, DR9 $(46,5,4,2,9)$ which may play a role similar to the one supratype $\mathrm{A} 1, \mathrm{~B} 8, \mathrm{C} 4 \mathrm{AQ} 0, \mathrm{C} 4 \mathrm{~B} 1$, BfS, DR3 does in whites. ${ }^{15}$ In a study by Dawkins et $a l,{ }^{16} 46, S, 4,2,9$ was found to be present in $72 \%$ of patients with myasthenia gravis with onset age of less than 12 years old.

The age at onset, among other variables determining the subgroups of myasthenia gravis, is most significant in relation to HLA differences. In the present study, the association is mainly in the juvenile group as in all

Table 3 Analysis of age at onset (years) in association with HLA-Bw46 and DR9.

\begin{tabular}{llll}
\hline & $B w 46(+) D R 9(+)$ & $B w 46(+) D R 9(-)$ & $B w 46(-) D R 9(+)$ \\
\hline Total & 50 & 10 & 28 \\
Age at onset & 35 & 5 & 10 \\
$\quad \leqslant 20$ & 15 & 5 & 18 \\
$\quad>20$ & $18.7(11.4)$ & $28.8(23.3)^{\star}$ & $28.8(18.0)^{\star \star}$ \\
\hline
\end{tabular}

${ }^{\star}$ Compared with Bw46(+)DR9(+), $t=2.09 \mathrm{p}<0.05$.

$\star \star C o m p a r e d$ with Bw46(+)DR9 $(+), t=3.03 \mathrm{p}<0.01$. previous reports from studies on Chinese. In whites, the age at onset is also an important determinant in correlating HLA frequencies and in subclassifying the disease: $\mathrm{A} 1, \mathrm{~B} 8$ and DR3 are associated with onset age below 40 and A3, B7 and DR2 are associated with onset age over $40 .^{2}$ Similar findings are noted in Japanese. Matsuki et al ${ }^{17}$ described a strong association of DR9, DRw13 and DQw3 and the association was strongest before three years of age and decreased thereafter. It is noteworthy that a few other autoimmune diseases share such age dependent difference and HLA association, notably insulin-dependent diabetes with B8DR3 or B15DR4 ${ }^{18}$ and juvenile rheumatoid arthritis with $\mathrm{B} 27$ or DR5. ${ }^{19}$ Both diseases are clearly distinct form their adult counterparts.

There is a major difference in the age-incidence of myasthenia gravis between whites and Chinese populations; in the Chinese, the disease often has an earlier onset and runs a more benign course with mainly ocular involvement. Whether this subgroup represents a separate entity or is merely an early presentation of the continuing spectrum of the disease is an issue of interest. In our study it is with this particular subgroup that Bw46DR9 is most closely associated, perhaps suggesting that the underlying immunopathogenesis differs in these subgroups. It can also be inferred that the differences of clinical manifestations between Chinese and white patients with myasthenia are immunogenetically based.

The Japanese population with myasthenia, on the other hand, resembles the Chinese in the large number of patients with juvenile and ocular myasthenia. In earlier studies of HLA associations in Japanese patients, the results were inconsistent and the associations often weak. Typing for DR9 has recently given more consistent results. Kida et al pointed out that DR9 was associated with ocular myasthenia gravis whereas DRw8 was associated with generalised disease. Although they did not specify the associations with age at onset, patients with their ocular myasthenia are clearly younger than those with generalised disease (mean (SE): 16.7 (3.2) v 26.3 (3.8)). Later, Morita et $a^{20}$ demonstrated an association with HLA-DRw53 as well as with DRw9 in early-onset disease in Japanese females and Matsuki et al $^{17}$ showed that the frequencies of DR9 and DRw13 were significantly increased in patients below three years of age. DR9 consistently showed the strongest association in juvenile Japanese patients, as in the Chinese. Interestingly, the Bw46DR9 haplotype was significantly increased in the Matsuki series, although it was only seen in five of 31 DR9 positive patients. The close relationship between Chinese and Japanese patient populations may suggest a common genetic background (table 4).

We do not have enough data on acetylcholine receptor antibody titre to be included in the present study and are therefore unable to discuss the association between HLA and 
Table 4 Comparison of HLA association in Chinese and fapanese.

\begin{tabular}{|c|c|c|c|c|c|}
\hline Author & Ethnic group & $\begin{array}{l}\text { Patient } \\
\text { number }\end{array}$ & $\begin{array}{l}\text { Control HLA } \\
\text { (frequencies(\%)) }\end{array}$ & HLA association(\%) & $M G$ subgroup \\
\hline $\begin{array}{l}\text { Hawkins }(1984)^{5} \\
\text { Lee }(1984)^{21} \\
\text { Hawkins }(1986)^{7}\end{array}$ & $\begin{array}{l}\text { Hong Kong Chinese } \\
\text { Shanghai Chinese } \\
\text { Hong Kong Chinese }\end{array}$ & $\begin{array}{l}27 \\
63 \\
37 \text { adults }\end{array}$ & $\begin{array}{l}\text { Bw46(26.4) } \\
\text { DR4(17.1) } \\
\text { Bw46(26.4) }\end{array}$ & $\begin{array}{l}\text { Bw46(67) } \\
\text { DR4 }(40 \cdot 1) \\
\text { Bw46(38.5 } \\
\text { Anti AchR < 1) }\end{array}$ & $\begin{array}{l}\text { Juvenile MG } \\
\text { Not stated } \\
\text { Adult MG without antiAchR }\end{array}$ \\
\hline Thajeb $(1987)^{6}$ & Taiwan Chinese & 65 & $\begin{array}{l}\text { A2 }(44 \cdot 8) \\
\text { DR9 }(8 \cdot 2)\end{array}$ & $\begin{array}{l}\text { A2 }(61 \cdot 5) \\
\text { DR9 }(24 \cdot 5)\end{array}$ & No correlation with subgroup \\
\hline Chiu $(1987)^{8}$ & Taiwan Chinese & 59 & $\begin{array}{l}\text { Bw46(13.9) } \\
\text { DR9(11.4) }\end{array}$ & $\begin{array}{l}\mathrm{Bw} 46(47 \cdot 5) \\
\operatorname{DR} 9(59 \cdot 3)\end{array}$ & Except onset age $>40$ \\
\hline $\begin{array}{l}\text { Hawkins } \\
(1989)^{14}\end{array}$ & Hong Kong Chinese & 194 & $\begin{array}{l}\text { Bw46(31) } \\
\text { DR9(21) }\end{array}$ & $\begin{array}{l}\text { Bw46(63.9, juvenile) } \\
\text { DR9(81.9, juvenile; } \\
47 \cdot 5 \text {, adult) }\end{array}$ & $\begin{array}{l}\text { Ocular, onset age }<20, \\
\text { absence or low antiAchR }\end{array}$ \\
\hline $\begin{array}{l}\text { Dawkins } \\
(1987)^{16}\end{array}$ & Hong Kong Chinese & 166 & $\begin{array}{l}\text { Bw46(29) } \\
\text { DR9(36.7) }\end{array}$ & $\begin{array}{l}\text { Bw46,BfS,C4A4,C4B2 } \\
\text { DRw9 supratype, } \\
\text { Bw46(47) } \\
\text { DR9 }(60 \cdot 8)\end{array}$ & Onset age $<12$ \\
\hline Kida $(1987)^{4}$ & Japanese & 71 & $\begin{array}{l}\text { DR9 }(29 \cdot 3) \\
\text { DRw8(36.7) }\end{array}$ & $\begin{array}{l}\text { DR9(54.9) } \\
\text { DRw8(59.2) }\end{array}$ & $\begin{array}{l}\text { Ocular } \\
\text { Generalized }\end{array}$ \\
\hline Morita $(1991)^{20}$ & Japanese & 46 & $\begin{array}{l}\text { DR9 }(21 \cdot 1) \\
\text { DRw53(64.0) }\end{array}$ & $\begin{array}{l}\text { DR9 } 937 \cdot 0) \\
\text { DRw53(78.3) }\end{array}$ & Early onset, female \\
\hline $\begin{array}{l}\text { Matsuki } \\
(1990)^{17}\end{array}$ & Japanese & 104 & $\begin{array}{l}\text { DR9(27) } \\
\text { DRw13(16) } \\
\text { B44(13) }\end{array}$ & $\begin{array}{l}\text { DR9 }(86 \% \text {, age } 0-2 ; \\
65 \text {, age 3-5) } \\
\text { DRw13(58,age 0-2) } \\
\text { B44(51, age 0-2) }\end{array}$ & Onset age $<3$ \\
\hline Present series & Taiwan Chinese & 152 & $\begin{array}{l}\text { Bw46(17.3) } \\
\text { DR9(15.0) } \\
\text { Bw46DR9 }(7 \cdot 0)\end{array}$ & $\begin{array}{l}\text { Bw46(43) } \\
\text { DR9(56) } \\
\text { Bw46DR9(36) }\end{array}$ & $\begin{array}{l}\text { Non-thymoma, onset age }<20 \\
\text { association is strongest with } \\
\text { Bw } 46 \text { DR } 9 \text { combination }\end{array}$ \\
\hline
\end{tabular}

AntiAChR = anti-acetylcholine receptor antibody.

acetylcholine receptor antibody titre, which was the main issue presented by Hawkins et $\mathrm{al}^{714}$ to suggest the presence of a variant of myasthenia gravis. As an alternative, we chose mean consecutive difference to represent the clinical severity; although not statistically significant the difference in the patients with Bw46, DR9 or Bw46DR9 tended to be lower.

The strong association with Bw46DR9 suggests that a susceptible gene for this subgroup of myasthenia lies in the haplotypes containing BW46/DR9. It is not an exclusive association, however, and perhaps use of probes for different class II loci will enable us to locate such genes more precisely.

This study was supported by grants from the National Science Council, Republic of China (NSC 77-0412-B002-50).

1 Chiu HC, de Lange GG, Willcox N, Vincent A, NewsomDavis J. Immunoglobulin allotypes in Caucasian and Chinese myasthenia gravis: differences from Japanese patients. F Neurol Neurosurg Psychiatry 1988;51:214-7.

2 Compston DAS, Vincent A, Newsom-Davis J, Batchelor JR. Clinical, pathological, HLA antigen and immunological evidence for disease heterogeneity in myasthenia logical evidence for disease heter
gravis. Brain 1980;103:579-601.

3 Christiansen FT, Pollack MS, Garlepp MJ, Dawkins RL Myasthenia gravis and HLA antigens in American Myasthenia gravis and HLA antigens in American
blacks and other races. $₹$ Neuroimmunol 1984;7:121-9.

4 Kida K, Hayashi M, Yamada I, et al. Heterogeneity in myasthenia gravis: HLA phenotypes and autoantibody responses in ocular and generalized types. Ann Neurol 1987;21:274-8.

5 Hawkins BR, Chan-Lui WY, Choi EKK, Ho AY. Strong association of HLA Bw46 with juvenile onset myasthenia gravis in Hong Kong Chinese. $\mathcal{F}$ Neurol Neurosur Psychiatry 1984;47:555-7.

6 Thajeb P, Chee CY, Huang CC. The distribution of HLA-A,B,DR antigens in Chinese myasthenia gravis. Tissue Antigens 1987;29:273-9.
7 Hawkins BR, Ip MSM, Lam KSL, et al. HLA antigens and acetylcholine receptor antibody in the subclassification of myasthenia gravis in Hong Kong Chinese. $f$ Neurol Neurosurg Psychiatry 1986;49:316-39.

8 Chiu HC, Hsieh RP, Hsieh KH, Hung TP. Association of HLA-DRw9 with myasthenia gravis in Chinese. $\mathcal{f}$ Immunogenet 1987;14:203-7.

9 Chiu HC, Hsieh RP, Hsieh KH. Association of HLA antigens with myasthenia gravis in Chinese on Taiwan. Chinese $\mathcal{F}$ Microbiol Immunol 1990;23:12-8.

10 Chiu HC, Vincent A, Newsom-Davis J, Hsieh KH, Hung TP. Myasthenia gravis: population differences in disease expression and acetylcholine receptor antibody titers between Chinese and Caucasians. Neurology 1987;37: 1854-7.

11 Ekstedt J, Nilsson G, Stalberg E. Calculation of the electromyographic jitter. F Neurol Neurosurg Psychiatry 1974;37:526-39.

12 Chiu HC. Single fiber electromyography in myasthenia gravis. 7 Formosan Med Assoc 1988;87:574-8.

13 Chan SH, Wee GB. Association of Bw46 and Cw1/Cw3 in Chinese. Tissue Antigens 1979;14:179.

14 Hawkins BR, Yu YL, Wong V, Woo E, Ip MSM, Dawkins RL. Possible evidence for a variant of myasthenia gravis based on HLA and acetylcholine receptor antibody in Chinese Patients. Quart $\mathcal{f}$ Med 1989;70: 235-41.

15 Dawkins RL, Christiansen FT, Kay PH et al. Disease associations with complotypes, supratypes and haplotypes. Immunol Rev 1983;70:5-22.

16 Dawkins RL, Hawkins BR, Gin W, Zhang WJ, Martin E, Christiansen FT. Association between myasthenia gravis and HLA Bw46, BfS, C4A4, C4B2, DRw9 in Chinese. In: Dupont B, ed. Immunobiology of HLA. Vol.II immunogenetics and histocompatibility. New York: Springer-Verlag, 1987:437-8.

17 Matsuki K, Juji T, Tokunaga $\mathrm{K}$ et al. HLA antigens in Japanese patients with myasthenia gravis. $\mathcal{f}$ Clin Invest Japanese patients

18 Tiwari JL, Terasaki PI. HLA and disease association. New York: Springer-Verlag, 1985:472.

19 Lotz M, Vaughan JH. Rheumatoid arthritis. In: Samter $\mathrm{M}$, ed. Immunological disease 4th ed. Boston: Little, Brown \& Company, 1988:1365-416.

20 Morita K, Moriuchi J, Inoko H, Tsuji K, Arimori S. HLA Class II antigens and DNA restriction fragment length polymorphism in myasthenia gravis in Japan. Ann Neurol 1991;29:168-74.

21 Lee TD, Zhao TM, Bu KJ, Lu CZ, Donnell MQ, Sandler SG. Association of HLA DR4 with myasthenia gravis in the Chinese. Tissue Antigens 1984;23:127-9. 